\title{
Neotectonic activity of the Bomdila Fault in northeastern India from geomorphological evidences using remote sensing and GIS
}

\author{
Jogendra Nath Sarma ${ }^{1}$ and Sangeeta Sharma ${ }^{2, *}$ \\ ${ }^{1}$ Department of Applied Geology, Dibrugarh University, Dibrugarh 786 004, Assam, India. \\ ${ }^{2}$ Geoscience Division, CSIR-North East Institute of Science and Technology, Jorhat 785 006, Assam, India. \\ ${ }^{*}$ Corresponding author.e-mail: sangees_online@rediffmail.com
}

MS received 15 July 2016; revised 26 February 2018; accepted 28 February 2018;

published online 29 September 2018

One of the major geological structures across the Brahmaputra valley, which stretches from the Eastern Himalayas up to the Naga Hills, is the Bomdila Fault. Parts of the courses of the rivers - the Brahmaputra, Dhansiri (south-S), Bargang and many others - are aligned along this structure. The influence of this structure on the courses of these rivers has been studied in detail using topographic maps, satellite data and field evidences. The signatures obtained such as: (a) an unusually linear course of the lower part of the Dhansiri (S) river from Golaghat up to Dhansirimukh, (b) the abandonment of the westerly course of the earlier Dhansiri (S) river (flowing through Kaziranga) towards the present NW direction by avulsion, (c) knick bends in the MBT-MCT and Naga Thrust of Belt of Schuppen, (d) a linear $15 \mathrm{~m}$ high topographic scarp on the left bank of the Dhansiri (S) near Numaligarh and (e) an anomalous SE-NW trending course of the Brahmaputra from Dhansirimukh up to Hartamuli along with the parts of the rivers Buroi and Bargang on the north in the same trend infers the influence of a fault-type structure. Since all these linear segments of the rivers align along the NW-SE trending Bomdila Fault, it infers the influence of the later on the courses of these rivers. The neotectonic activity along this fault might have caused the linear high scarp and abandonment of earlier river courses.

Keywords. Geological structure; neotectonic activity; Bomdila Fault; avulsion; scarp.

\section{Introduction}

Neotectonics refers to recent tectonic movements that occurred in the upper part of Tertiary (Neogene) and in the Quaternary, which played an essential role in the origin of the contemporary topography (Obruchev 1948). It is the prime factor that governs the sedimentation pattern and geomorphic evolution in active fault zones (Chowksey et al. 2011). The term neotectonics was first proposed by Obruchev (1948) to denote the active geological processes. The geomorphological evidences of neotectonic morphology are development of terraces, active faulting, upliftment, development of tectonic depression and ridges, springs, sag ponds, fault scarps, off-set drainages and triangular facets (Schubert 1982). Anomaly identification and interpretation of these various geomorphic evidences integrate to form neotectonic study of any region.

The northeastern region of India is jawed in between the Himalayan collision arc to the north and northeast and the Indo-Burmese subduction arc to the south and southeast (Murthy et al. 1969; 


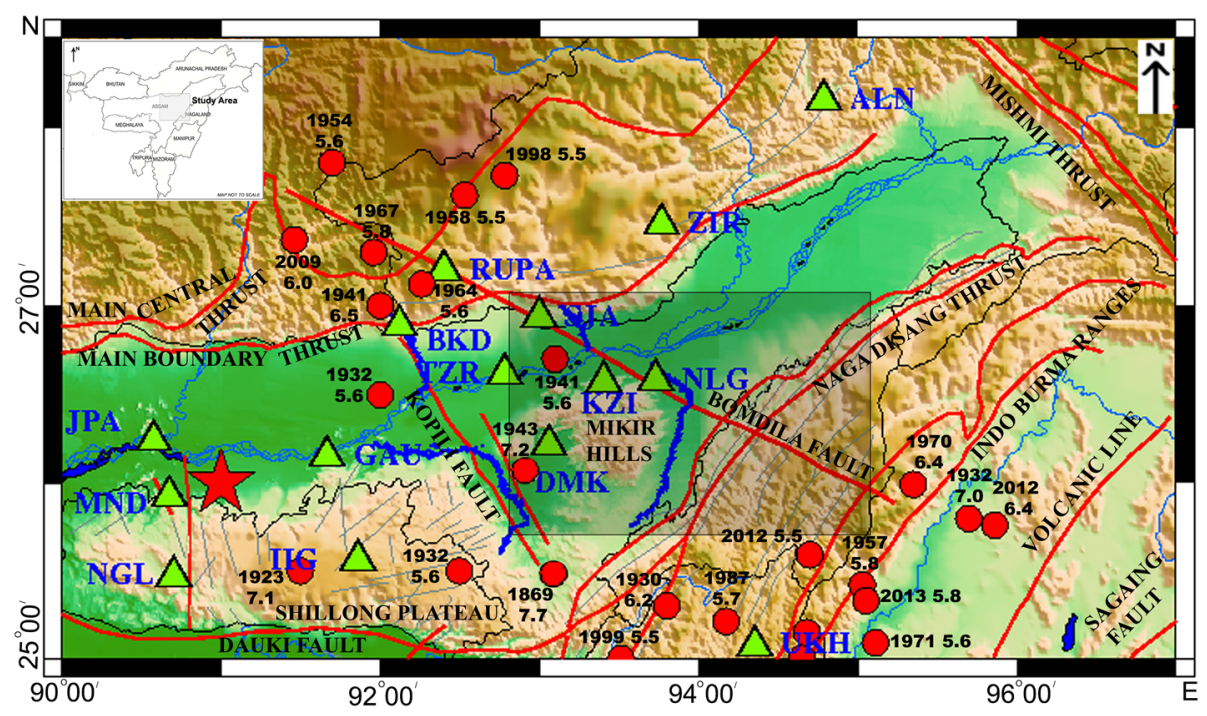

Figure 1. Location map of the study area (within latitudes $25^{\circ} 40^{\prime}-27^{\circ} \mathrm{N}$ and longitudes $93^{\circ}-95^{\circ} \mathrm{E}$ shaded in grey) showing major earthquakes along with major tectonic features (red lines) in northeast India region (modified after Murthy et al. 1969; Nandy 2001; Baruah and Hazarika 2008). The great 1897 earthquake $\left(M_{\mathrm{S}} \sim 8.7\right)$ in the region is shown by star and the large earthquakes $\left(M_{\mathrm{b}} \geq 5.5\right)$ by circles. The digital seismic stations are shown by green triangles.

Nandy 2001; Baruah and Hazarika 2008) (figure 1). This region is tectonically divided into several mosaics by deep-rooted faults/thrust along which episodic block/thrust/strike-slip movements are reported (Nandy 1986, 2001). Besides these tectonic domains, a number of faults are found to be very active (Biswas et al. 2007). The Bomdila Fault in the Dhansiri (south - S) and Bargang valleys is one of them, which is evidenced from the occurrence of large magnitude $\left(M_{\mathrm{b}} \geq 5.5\right)$ seismic events in the recent past (Murthy et al. 1969; Nandy 2001; Baruah and Hazarika 2008) (figure 1). The fault having its extent $\sim 400 \mathrm{~km}$ lies in a tectonically active region which criss-crosses the MCT, MBT and Naga-Disang Thrust along the NW-SE direction. Most of the seismic events that occur along this fault have shallow focus depth (Kayal 2008) except for a few events in the NW trending wedge-shaped block lying in between the Kopili and the Bomdila Faults. The earthquake events in this tectonic block occur in a diffused pattern having post-collisional intracratonic characteristics (Nandy and Dasgupta 1991). Focal mechanism solutions reveal the left lateral shear along the NW nodal plane for the Bomdila Fault which are perhaps related to the strike-slip movements along this fault (Nandy 1981). Chen and Molnar (1990) obtained predominantly thrust movements with strike-slip component having NNE-SSW pressure axis, focal depth being at $36 \mathrm{~km}$.

Another important constituent of Assam shelf of Assam-Arakan Basin is Dhansiri (S) valley which is regarded as one of the commercial hydrocarbon producing provinces of the region. So, Oil and Natural Gas Commission and many researchers such as Dasgupta (1977), Chopra (1982), Dasgupta et al. (1987), Janardhan and Gohain (1991), Surendranath and Sarmah (1992), Nandy (2001), Kotoky et al. (2005) and Dutta (2007) have carried out some studies on geology and geomorphology of this region. However, neotectonic study in this valley has not been attempted so far. Here, the main objective of the study is to examine the influence of Bomdila Fault in controlling and modifying the river alignments and topography of the area due to its neotectonic activity.

\section{Study area}

The study area covers a part of the Bomdila Fault in and around the Dhansiri (S) and Bargang river valleys of northeast India that lies within longitudes $93^{\circ} 00^{\prime}-94^{\circ} 30^{\prime} \mathrm{E}$ and latitudes $25^{\circ} 40^{\prime}-27^{\circ} 00^{\prime} \mathrm{N}$ (Dasgupta 1977; Nandy 2001) (figure 2). Parts of the rivers namely, the Dhansiri (S), which lie in the south bank of the river Brahmaputra, the Brahmaputra itself and the Bargang, which lie in the north bank, are undertaken for the study. The Dhansiri (S) is an important south-bank tributary of the mighty Brahmaputra and is considered as one of the most highly meandering rivers of the world (Dutta 2007). The area under study lies in the Survey of India (SoI) topographic map nos. $83 \mathrm{E} / 4,83 \mathrm{~F} / 1,83 \mathrm{~F} / 5,83 \mathrm{~F} / 10$, 


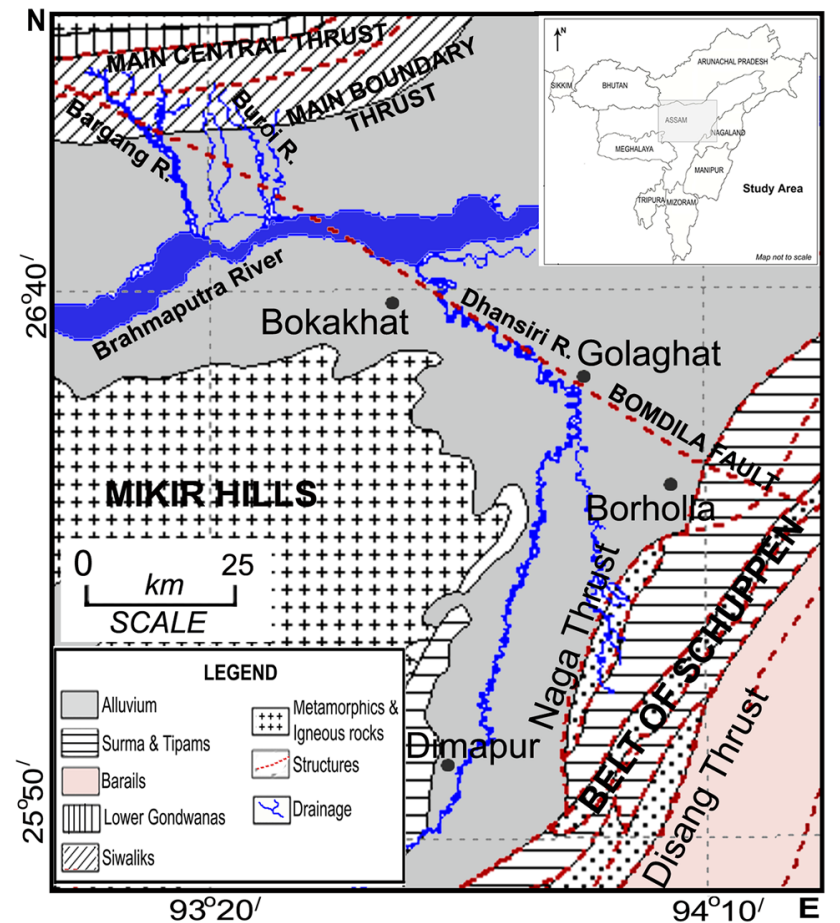

Figure 2. Geological map of the study area showing the major structures (modified after Dasgupta 1977; Nandy 2001).

$83 \mathrm{~F} / 14,83 \mathrm{~F} / 15,83 \mathrm{~F} / 16,83 \mathrm{G} / 9,83 \mathrm{G} / 13,83 \mathrm{~J} / 3$ $83 \mathrm{~F} / 6,83 \mathrm{~F} / 9$ in $1: 50,000$ scale and degree sheet ng46_7 jorhat.

\section{Geology and tectonics}

Geologically, the Dhansiri (S) river basin lies in the Assam-Arakan Basin, which represents a classic example of a poly-tectonic basin having history of more than one phase of tectonics and sedimentation (Reddy et al. 2008). The evolution of the basin is essentially influenced by the movement of the Indian plate in relation to the Eurasian and Burmese plates. The Dhansiri (S) and Bargang valleys comprise mostly Palaeogene and Neogene sediments in subsurface and recent alluvium on the surface (Dasgupta 1977; Nandy 2001) (figure 2). In our study area, the sub-Himalaya is represented by the Siwalik Group, which has a faulted contact (Himalayan Frontal Thrust) with the Brahmaputra alluvium in the south. Towards the north, the sub-Himalaya is thrusted over the Lesser Himalaya along the Main Boundary Thrust, which is represented by the Gondwana Group. These are overlain by medium-to-high-grade metamorphic and igneous rocks.
Tectonically, the Dhanisri $(\mathrm{S})$ valley lies in the south Assam shelf. It is bounded to the east and south by the Belt of Schuppen, to the west by the Mikir Massif and to the north by the Jorhat Fault. The Himalayan folded belt lies in the north of the Bargang river. The main fault through the Dhansiri (S)-Brahmaputra-Bargang river valleys is the NW-SE trending Bomdila Fault, which also cuts across the Himalayan fold belt in the north as well as the Belt of Schuppen in the south (Dasgupta 1977; Nandy and Dasgupta 1991; Nandy 2001) (figure 2). Characteristically, the fault is considered to be strike-slip in nature.

\section{Methodology}

The present study aims at the study of geomorphology and the influence of neotectonics in the area. Geomorphological studies are carried out to identify the drainage patterns, drainage anomalies, lineaments, topography, swamps/bils and palaeochannels to find out the evidences of neotectonism. The river courses are drawn from the SoI topographic maps of 1:50,000 scale surveyed during 1959-1968. These topographic maps are georeferenced and digitised in the GIS software ILWIS3.4 in the Universal Transverse Mercator (UTM) projection system. The SoI maps are supplemented by satellite images of LISS III (December 2004), ETM7+ (December 2001; March 2010) and TM (November 2011) of rows 41 and 42 and paths 135 and 136 . The satellite data depict the present courses of the rivers by which we can demarcate the changes occurred during the period (1959-2010). These imageries are stacked and processed in ERDAS Imagine 8.5 and the rivers are digitised and overlapped to study the changes.

The river courses considered are the Dhansiri (S) from Chumukedima at the foothills to the mouth of the river near Dhansirimukh on the southern bank of the river Brahmaputra, the Brahmaputra proper and the rivers Bargang and Buroi on the northern bank of the Brahmaputra. Extensive fieldwork is done to collect neotectonic evidences and to delineate the misfit river/abandoned channel, fault scarp in the field. Field evidences of some identified locations are collected within the study area. Mapping of the neotectonic movements is derived from these field evidences along with the indirect evidences collected from the existing literatures on geological, seismological and geophysical data as well. Topographical relief studies 
are performed through the topographical profiles across the Bomdila Fault using the Shuttle Radar Topography Mission (SRTM) digital elevation model (DEM) with $90 \mathrm{~m}$ spatial resolution in World Reference System dated 2000 (www.srtm. csi.cigar.org). The SRTM DEM is georeferenced with respect to SoI maps in the Universal Transverse Mercator (UTM) projection system. The study areas were extracted and the images were processed in Global Mapper 11. In order to carry out the seismotectonic study, primarily a database of 9376 earthquake events consisting of hypocentral parameters are prepared during the period 19842015. Seismicity data are collected from the seismological bulletin published annually by the CSIR North East Institute of Science and Technology (NEIST), Jorhat and CSIR National Geophysical Research Institute (NGRI), Hyderabad. The barest minimum magnitude of the earthquake events is considered to be 1.5. The uncertainties involved in the estimates of origin time for these events are 0.03-0.1 s. On the other hand, the uncertainties involved in the estimates of longitude and latitude of epicentres lie within the range of $0-2 \mathrm{~km}$. The epicentral map utilising the databases has been plotted covering the area between latitudes $25^{\circ}$ and $28^{\circ} \mathrm{N}$ and longitudes $90^{\circ}$ and $97^{\circ} \mathrm{E}$ to observe the spatial distribution of the epicentres using the GMT software (http://gmt.soest.hawaii. $\mathrm{edu} /$ ). For a better understanding of the neotectonics of the region and to find out the evidences that support the findings of a thorough study in the existing literatures and maps on geological, geophysical, seismic profiles by different workers are compiled and correlated.

\section{Results and discussion}

The indication of the ongoing neotectonic activity in the study area is derived from geomorphological evidences such as straight river courses and similar alignment over different river courses, change in trends of the regional structures, presence of scarp and abandoned (=Mora) river channels, etc. The details of the evidences are given below.

\subsection{Stream alignments}

The SSW-NNE trending meander belt of Dhansiri $(\mathrm{S})$ river takes a sudden northwesterly trend at Golaghat and maintains a straight path for next $65 \mathrm{~km}$ up to its confluence with the Brahmaputra at Dhansirimukh (figure 3). After taking

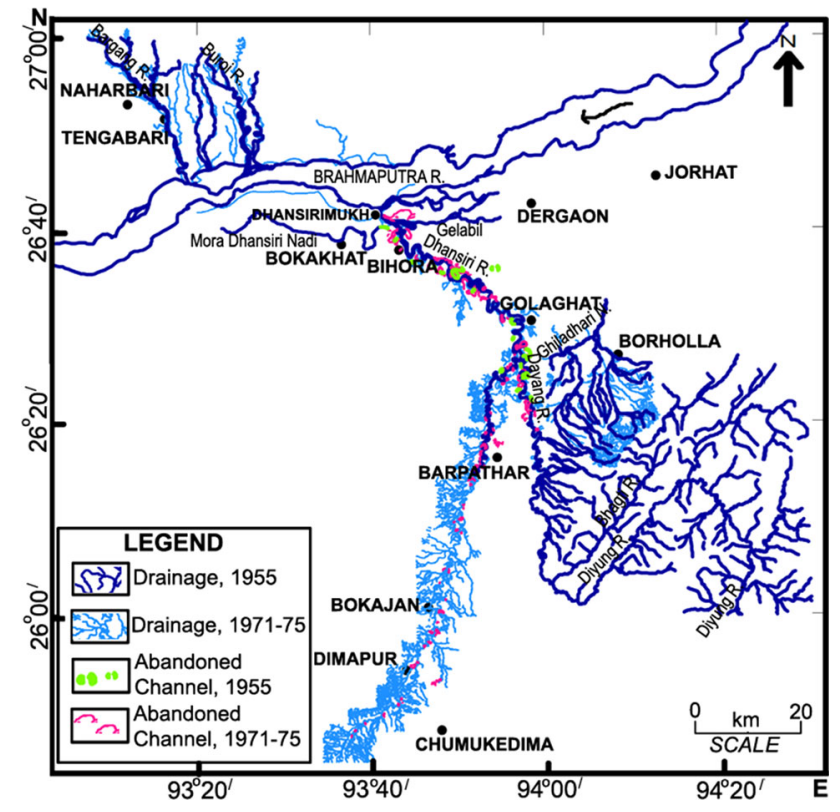

Figure 3. Figure showing the overlap of the south DhansiriBargang drainage pattern for the periods 1955 (1:250,000 scale) and 1971-1975 (1:50,000 scale).

on the Dhansiri (S), the southwesterly flowing Brahmaputra also suddenly trends towards northwest along the direction of the lower part of the Dhansiri (S). This is more clearly observed in the LISS III imagery (figure 4) and in the map of 1:250,000 scale (1971-1975 period) (figure 3). After flowing for $25 \mathrm{~km}$ along this trend, the Brahmaputra takes on the river Buroi and thereafter it turns again southwesterly parallel to its course on the upstream of Dhansirimukh. The river Buroi also has a liner course in the NW-SE trend aligned parallel to the trend of the Dhansiri (S). The Brahmaputra flows for a distance of about $16 \mathrm{~km}$ in the southwesterly direction from the mouth of the river Buroi and takes on the river Bargang. The Bargang river is a nearly NNW-SSE trending river from its mouth to Tengabari. At Tengabari, the upper course of the Bargang takes a NW-SE trend, which is aligned along the direction of the Dhansiri (S) river course from Golaghat up to Dhansirimukh (figures 3 and 4).

Towards east of Golaghat, many small rivers have NW-SE trending courses along the direction of the Dhansiri (S). These streams are the parts of the Nalajan, Ghiladhari, Makrang, Kakadanga and Naginijan. Within the Naga Hills the same trend can be followed along a part of the course of the river Diyung/Dayang (figure 3). The river Diyung/Dayang, which has a northeasterly course, takes a sudden northwesterly trend aligned along 


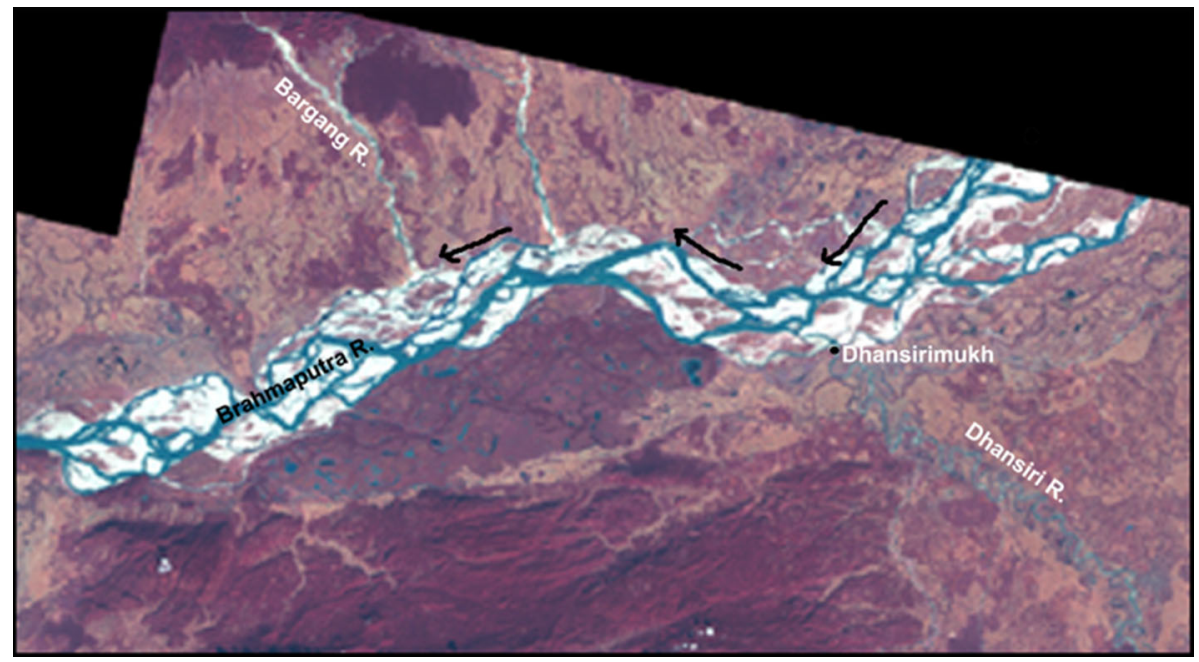

Figure 4. LISS III Imagery showing the stream alignments of the Dhansiri (S), sudden NW trend of the Brahmaputra and the Bargang rivers.

the trend of the Dhansiri (S). All these alignments can be related to the Bomdila Fault.

\subsection{Change in river courses}

The Gelabil river, a tributary of the Dhansiri (S), has a nearly E-W slightly sinuous course. In the past, immediately after taking on the Gelabil, the Dhansiri (S) flowed to the west along the course of the present Mora Dhansiri river. The Mora Dhansiri river is now a misfit river, which flows through Kaziranga National Park, but it retains its earlier name prefixed by Mora (=dead). Although the Gelabil is a slightly sinuous river, the Mora Dhansiri river has a characteristic meandering channel similar to the main course of the Dhansiri (S) river. At that time the most downstream segment of the present Dhansiri river from Kurabahi to Dhansirimukh (at the confluence of Brahmaputra) trending in the NW direction was non-existent (figure 5a). It is likely that due to movement along the Bomdila Fault, the area to the east of the fault might have subsided and therefore, the westerly flow of the river Dhansiri (S) at Kurabahi was blocked leading to abandonment of its westerly course. Hence, the abandoned river is now called the Mora Dhansiri river, which is nourished only by rainwater. Thereafter, the Dhansiri river might have been compelled to flow along the fault line towards the NW direction to meet the Brahmaputra (figure 5b). The scarp on the left bank of the river at Numaligarh tea garden might have formed due to subsidence of the eastern part of the fault (figure 6).

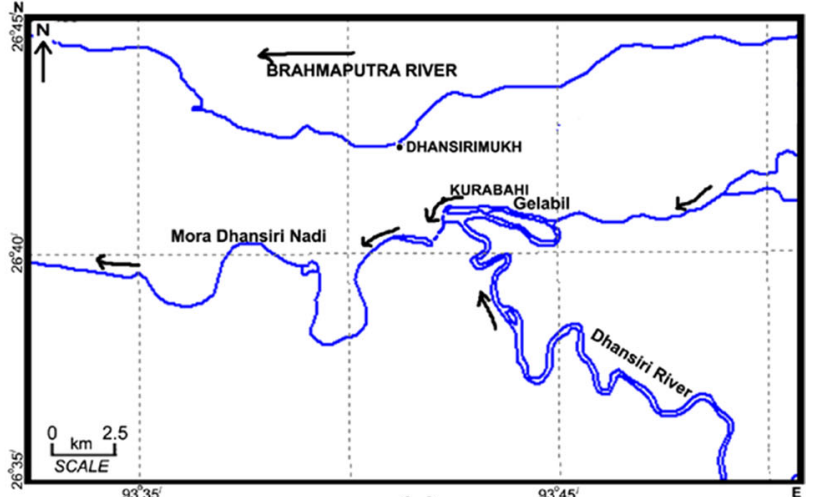

(a)

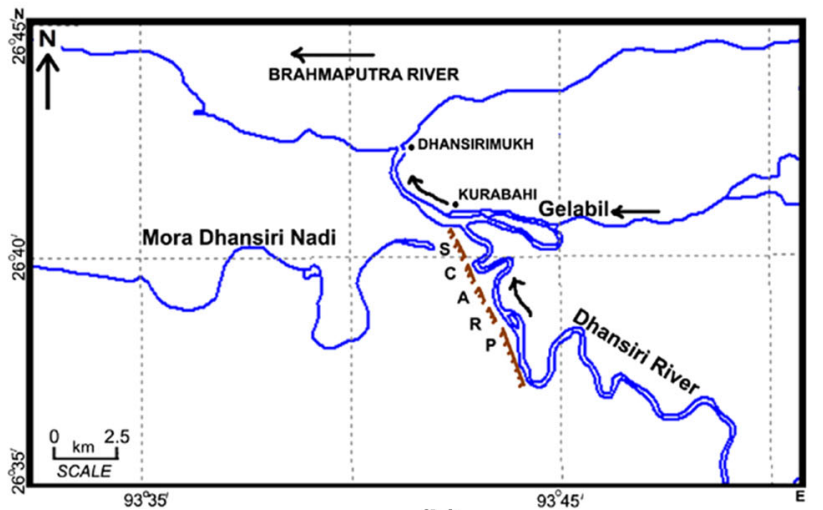

(b)

Figure 5. The course of the Dhansiri (S) river (a) shows the earlier E-W course of the Dhansiri (S) river with Gelabil along the present Mora Dhansiri river and (b) the present SE-NW course of the Dhansiri (S).

\subsection{Knicks on major structures}

The extension of the Mikir Hills plateau is limited to the east by the river Dhansiri (S). The Naga 


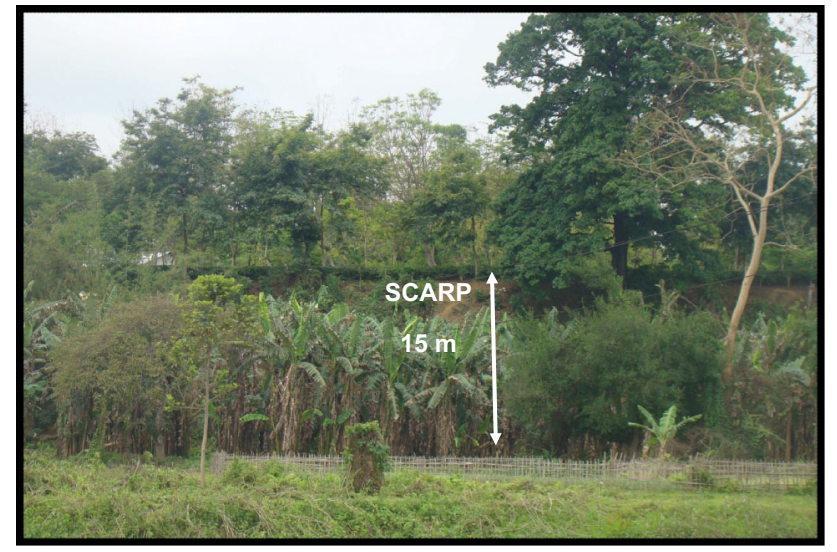

Figure 6. About $15 \mathrm{~m}$ high scarp near the NH37 around Numaligarh T.E. on the left bank of the South Dhansiri river (location: $26^{\circ} 37^{\prime} 50.8^{\prime \prime} \mathrm{N}$ and $93^{\circ} 43^{\prime} 47.1^{\prime \prime} \mathrm{E}$ ).
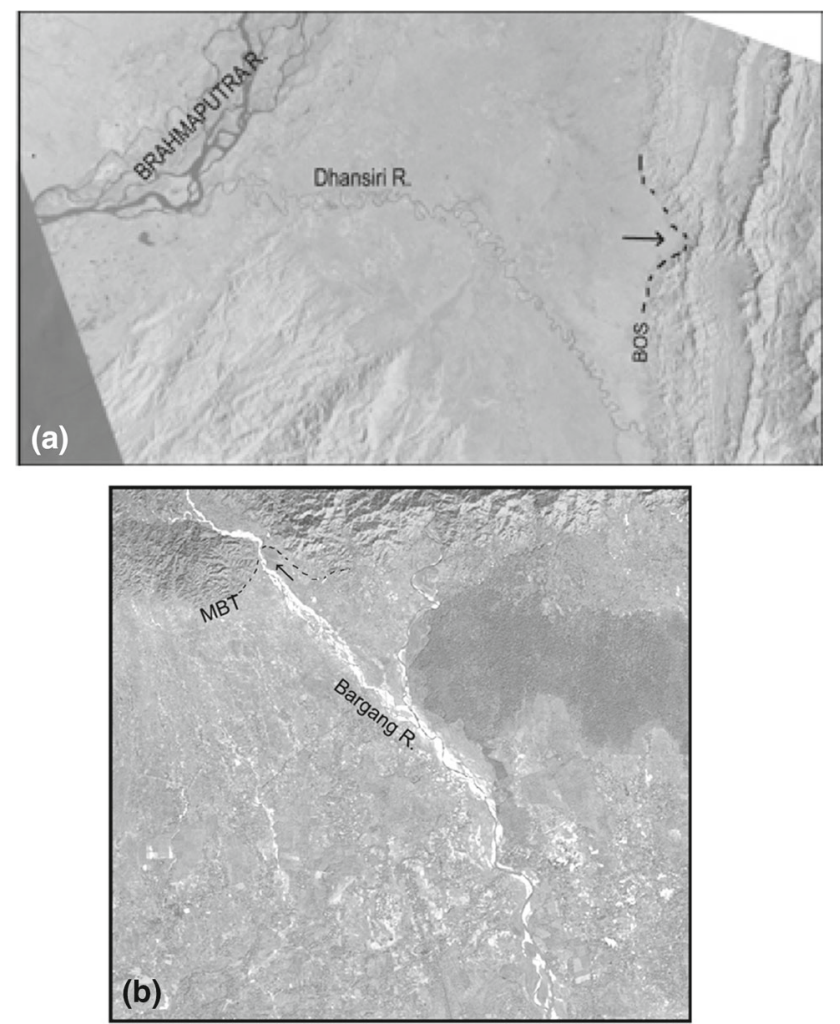

Figure 7. ETM7+ satellite image showing the change in the trend of (a) the Naga Thrust at the southern end (at the foothills), where the Naga Thrust meets the Bomdila Fault and (b) the MBT-MCT at the northern end where the thrust meets the Bomdila Fault. The sudden change in the trend of the formations can clearly be depicted.

Thrust of the Belt of Schuppen shows a distinct change in its trend at the foothills of the Naga Hills where the thrust meets the Bomdila Fault (figure 7a). Moreover, the Main Boundary Thrust and Main Central Thrust also show knick if the lineament is extended up to same on the north
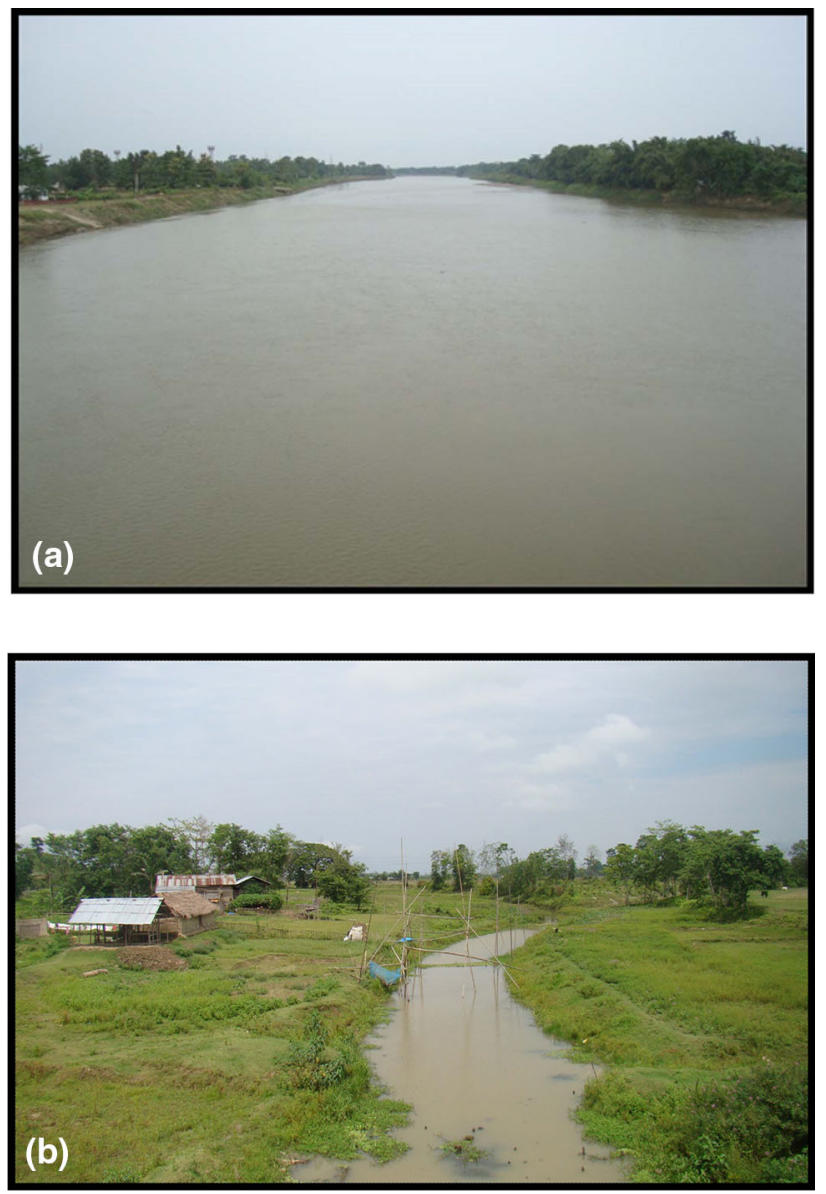

Figure 8. Showing the river courses of (a) the Dhansiri (S) river which is a straight course at Numaligarh along the scarp (location: $26^{\circ} 37^{\prime} 52.28^{\prime \prime} \mathrm{N}$ and $93^{\circ} 43^{\prime} 57.39^{\prime \prime} \mathrm{E}$ ) and (b) the present Mora Dhansiri (S) river near Bokakhat which behaves as a misfit stream (location: $26^{\circ} 38^{\prime} 56.5^{\prime \prime} \mathrm{N}$ and $\left.93^{\circ} 36^{\prime} 24.5^{\prime \prime} \mathrm{E}\right)$.

(figure 7b). These knicks infer that the Bomdila Fault had also influenced the trends of the major regional structures.

\subsection{Presence of a scarp}

The presence of a prominent $15 \mathrm{~m}$ high scarp as mentioned earlier along the left bank of the Dhansiri (S) river near Numaligarh (figure 6) surely reflects another evidence of neotectonic activity. This scarp is aligned parallel to the Dhansiri (S) river and the meandering course of the river is unusually straight along the base of this straight scarp (figure 8a). It is likely that some activities along the Bomdila Fault might have led to the formation of this scarp which resulted in the abandonment of the combined westerly course of the flow of the earlier Gelabil and Dhansiri (S) rivers through the Mora Dhansiri river (figure 8b). 


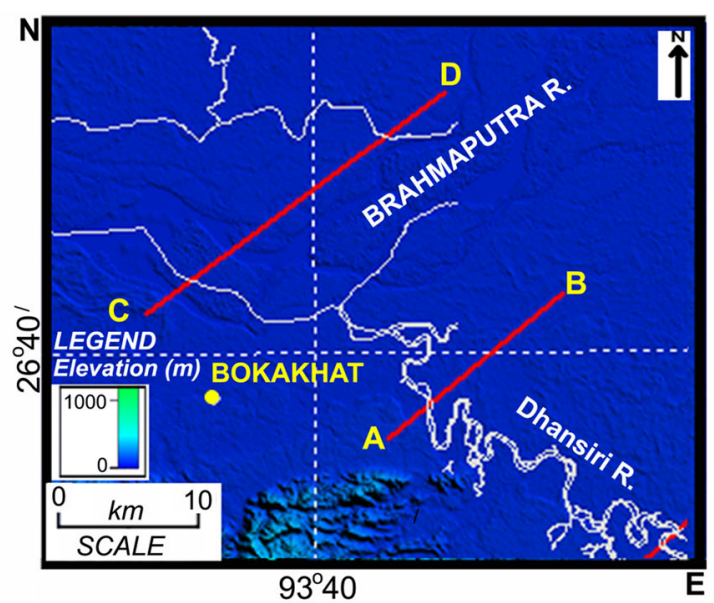

From Pos: 570555.585, 2944391.901To Pos: 580679.667, 2952931.943

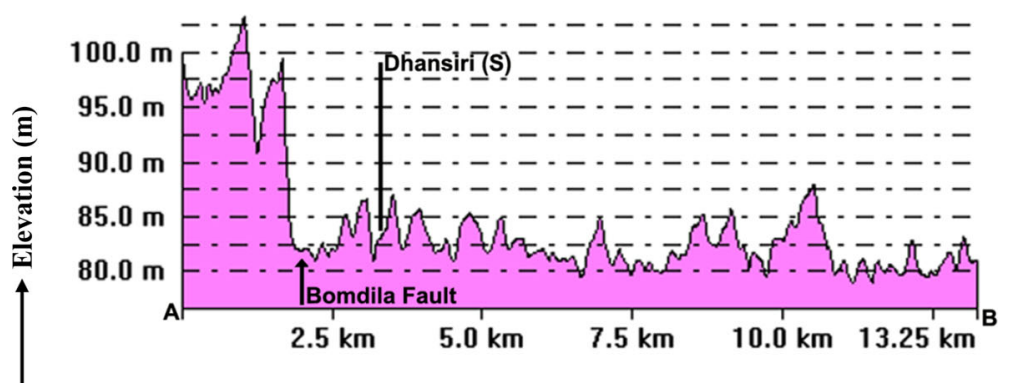

From Pos: 556742.129, 2951833.392To Pos: 574177.722, 2964637.655

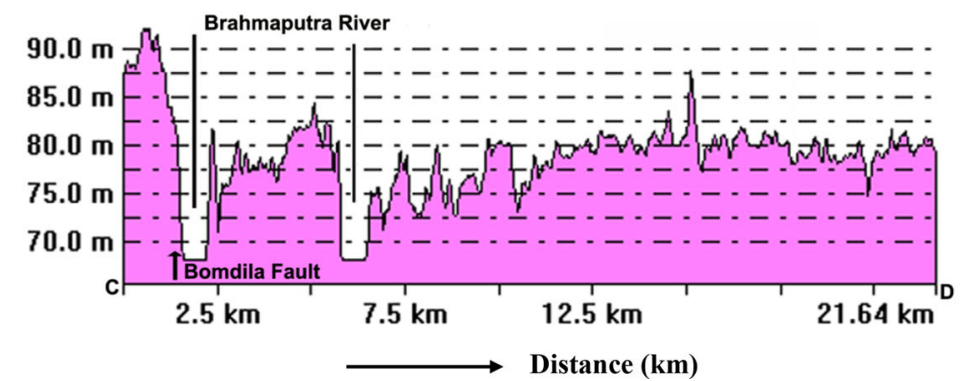

Figure 9. Location map and topographical profiles along (A and $\mathbf{B})$ and $(\mathbf{C}$ and $\mathbf{D})$ across the rivers Dhansiri $(\mathrm{S})$ and Brahmaputra, respectively.

\subsection{Topographic profiles}

Using DEM from SRTM data, 12 topographic profiles were drawn across the courses of the rivers Dhansiri (S) and the Brahmaputra to examine the relationship between the Bomdila Fault and the latter. Out of these only two representative profiles (A-B and $\mathrm{C}-\mathrm{D})$ are discussed here as examples (figure 9). All these profiles show that the position of the Bomdila Fault is marked by a sudden break in slope. As observed in the profile $\mathrm{A}-\mathrm{B}$, the area to the west of the river Dhansiri $(\mathrm{S})$ is about $15 \mathrm{~m}$ higher than the area to the east. The alignment of the Bomdila Fault shows that it passes through the point where there is a sharp contrast in the slope. It is noteworthy that a $15 \mathrm{~m}$ high prominent linear topographic scarp is present close to the river Dhansiri (S) (figure 6). Along the profile $\mathrm{C}-$ $\mathrm{D}$ it is observed that the Bomdila Fault lies just close to the western bank of the Brahmaputra river channel. In the same manner, the Bomdila Fault can be traced on other profiles also where there are sharp differences in elevation.

\subsection{Seismicity pattern}

From the epicentral map of major earthquakes $\left(M_{\mathrm{b}} \geq 5.5\right)$ along the Bomdila Fault (figure 1), it is seen that the fault remains active towards its northern, western and southern parts which portrays active tectonics in the region. Even though the fault has not produced any great earthquakes, 
earthquakes of $M_{\mathrm{b}} \geq 5.5$ can be observed towards the northern and the southern parts of the fault indicating the active tectonics.

\subsection{Geological evidences}

The Bomdila Fault is a nearly $400 \mathrm{~km}$ long fault, which extends WNW-ESE across the Himalaya and the plains of Assam up to the Belt of Schuppen. The fault passes through Dirang in Arunachal Pradesh on its northwestern part $\left(27^{\circ} 24^{\prime} 44.37^{\prime \prime} \mathrm{N}\right.$, $92^{\circ} 14^{\prime} 29.80^{\prime \prime} \mathrm{E}$ ) and lies in between Golaghat and Borholla on its southeastern part $\left(26^{\circ} 28^{\prime} 50.73^{\prime \prime} \mathrm{N}\right.$, $\left.94^{\circ} 09^{\prime} 36.01^{\prime \prime} \mathrm{E}\right)$. Some geological evidences support its existence as available from the cited areas are given below.

An analysis of structures in and around Dirang reveals that the rocks have suffered four phases of deformation D1, D2, D3 and D4. These structures have been grouped into (i) early structures, (ii) structures related to progressive ductile thrusting and (iii) late structures (Srivastava et al. 2011). These deformations might be associated with the Bomdila Fault. Moreover, the strain map prepared by United States Geological Survey (USGS) (Kreemer et al. 2003) also indicates a high strain $\left(64-500 \times 10^{-9}\right.$ nanostrain/yr) along the entire length of the Bomdila Fault (Sharma and Baruah 2017). An investigation on the substructural features along the Bomdila Fault, as evidenced by TWT (two-way travel time) structure map near to basement, indicates the presence of a structural high associated with a fault on the west of Golaghat. The downthrown block of the fault lies in the east of Golaghat towards Borholla (Akhtar et al. 2009), which may also support field evidence such as scarps. Besides, the clusters of epicentres of 4.0-4.5 and 5.0-5.5 magnitude earthquakes close to the Bomdila Fault on the NW of Bomdila and 5.0-5.9 and 6.0-6.9 magnitude earthquakes along the Bomdila Fault on the southeast of Golaghat indicate that the fault is seismically active (Narula et al. 2000).

\section{Conclusions}

It is apparent from this study that the Bomdila Fault has resulted in the development of some geomorphic features in the area indicating its neotectonically active nature. Parts of the courses of the rivers Dhansiri (S), Brahmaputra, Buroi, Bargang and some other streams in the southern foothills are developed under the influence of this linear structure. The abandonment of the westerly course of the earlier Dhansiri (S) river (flowing through Kaziranga presently known as the Mora Dhansiri river) towards the present NW direction by avulsion, knicks in MBT, MCT and Belt of Schuppen, presence of a linear $15 \mathrm{~m}$ high topographic scarp on the left bank of the Dhansiri (S) near Numaligarh strongly deduces the influence of the ongoing tectonic activity in the area due to the Bomdila Fault. The topographical profiles along with the seismicity pattern also supplement the ongoing tectonics in the area. It is observed that the Bomdila Fault intersect these profiles where there are breaks in slopes. The $15 \mathrm{~m}$ high prominent linear topographic scarp close to the river Dhansiri ( $\mathrm{S}$ ) is also very clearly discerned from the topographic profile. These evidences prove the neotectonic activity of the Bomdila Fault, which controls and modifies the river alignments and topography of the area which is substantiated by the local geology as well.

\section{Acknowledgement}

One of the authors (SS) is grateful to the Director, CSIR-North East Institute of Science and Technology, Jorhat, for granting the permission to carry out the study.

\section{References}

Akhtar S M, Chakrabarti S, Singh R K, Moulik S R, Bhattacharya J and Singh H 2009 Structural style and deformation history of Assam \& Assam Arakan Basin, India: From integrated seismic study; Adapted from oral presentation at AAPG Annual Convention, Denver, Colorado, 7-10 June 2009.

Baruah S and Hazarika D 2008 A GIS based tectonic map of northeastern India; Curr. Sci. 95 176-177.

Biswas S, Coutand I, Grujie D, Hager C, Stöckli D and Grasemann B 2007 Exhumation and uplift of the Shillong plateau and its influence on the eastern Himalayas: New constraints from apatite and zircon (U-Th- $[\mathrm{Sm}]) / \mathrm{He}$ and apatite fission track analyses; Tectonics $\mathbf{2 6}$ TC6013, https://doi.org/10.1029/2007TC002125.

Chen W P and Molnar P 1990 Source parameters of earthquakes and intraplate deformation beneath the Shillong Plateau and northern Indo-Burma ranges; J. Geophys. Res. 95 12,527-12,552.

Chopra S 1982 Geological mapping and related studies of geomorphological and fluvial processes in the Lower Kopili Basin, District Nowgong, Assam; Geological Survey of India, Progress Report for 1974-75 F.S., 14p. 
Chowksey V, Maurya D M, Joshi P, Khonde N, Das A and Chamyal L S 2011 Lithostratigraphic development and neotectonic significance of the Quaternary sediments along the Kachchh Mainland Fault (KMF) zone, western India; J. Earth Syst. Sci. 120(6) 979-999.

Dasgupta A B 1977 Geology of Assam Arakan region; Mining Metall. Soc. India Q. J. 49 1-54.

Dasgupta S, Mukhopadhyay M and Nandy D R 1987 Active transverse features in the central portion of the Himalaya; Tectonophys. 136 255-264.

Dutta M K 2007 Dhansiri River Channel, Assam - A geomorphologic attribute; Unpublished Ph.D. Thesis, submitted to Dept. of Applied Geology, Dibrugarh University, 197p.

Janardhan K and Gohain B N 1991 Quaternary geology and geomorphology of Brahmaputra valley in parts of Morigaon and Nowgong Districts, Geological Survey of India Progress Report of the Field Season 1989-1990, 19p.

Kayal J R 2008 Microearthquake seismology and seismotectonics of South Asia; Springer, Heidelberg, Germany, 503p.

Kotoky P, Bezbaruah D, Baruah J and Sarma J N 2005 Nature of bank erosion along the Brahmaputra river channel, Assam, India; Curr. Sci. 88(4) 634-640.

Kreemer C, Holt W E and Haines A J 2003 An integrated global model of present-day plate motions and plate boundary deformation; Geophys. J. Int. 154 8-34.

Murthy M V N, Talukdar S C and Bhattacharya A C 1969 The Dauki fault of Assam; Bull. Oil Nat. Gas Comm. 6 $57-64$.

Nandy D R 1981 Tectonic pattern in NE India - A discussion; Indian J. Earth Sci. 8(1) 82-86.

Nandy D R 1986 Tectonics, seismicity and gravity of northeastern India and adjoining region; Geol. Surv. India Memoir 119 13-17.

Corresponding editor: N V Chalapathi RaO
Nandy D R 2001 Geodynamics of Northeastern India and the adjoining region; ACB Publication, Kolkata, 209p.

Nandy D R and Dasgupta S 1991 Seismotectonic domain of northeastern India and adjacent areas; Phys. Chem. Earth 18 371-384.

Narula P L, Acharyya S K and Banerjee J (eds) 2000 Seismotectonic atlas of India and its enviorns; Geological Survey of India, Special Publication 5987.

Obruchev V A 1948 Osnovnye cherty kinetiki i plastiki neotektonik; Izv. Akad. Nauk. Ser. Geol. 5 13-24.

Reddy G V, Saha T, Chowdhury B K, Sekhar N C, Das N G, Sharma V and Sivaramakrishnan T E 2008 Analysis of Kalyanpur Field Discovery in Low Resistivity Silty Reservoir in Dhansiri valley, A\&AA Basin, Assam - A case study; In: 7th International conference $\&$ exposition on petroleum geophysics, Hyderabad, 170p.

Schubert C 1982 Geologia glacial del Páramo El Batallon, Estado Tachira Venezuela; Acta. Cient. Venezolana 33 $66-71$.

Sharma S and Baruah S 2017 Modelling of the Kopili fault based on slip rate, moment rate and seismic activity in Mikir hills plateau of northeastern India; Geomatics Nat. Hazards Risk, https://doi.org/10.1080/19475705. 2017.1300609.

Srivastava H B, Srivastava V, Srivastava R K and Singh C K 2011 Structural analyses of the crystalline rocks between Dirang and Tawang, west Kameng District, Arunachal Himalaya; J. Geol. Soc. India 78 45-56.

Surendranath M and Sarmah G C 1992 Quaternary geology and geomorphology of parts of the Brahmaputra valley in parts of Nagaon and Golaghat Districts, Assam; Geological Survey of India Progress Report for F.S. 1989-1990, 50p. 